\title{
Anti-metastatic and differential effects on protein expression of epigallocatechin-3-gallate in HCCLM6 hepatocellular carcinoma cells
}

\author{
YUNJUAN ZHANG ${ }^{1}$, LAWRENCE OWUSU $^{1}$, WEI DUAN ${ }^{2}$, TAO JIANG $^{1}$, \\ SHIZHU ZANG ${ }^{1}$, AYAZ AHMED ${ }^{1}$ and YI XIN ${ }^{1}$ \\ ${ }^{1}$ Department of Biotechnology, Dalian Medical University, Dalian, Liaoning, P.R. China; \\ ${ }^{2}$ School of Medicine, Deakin University, Victoria, Australia
}

Received March 11, 2013; Accepted May 16, 2013

DOI: $10.3892 /$ ijmm.2013.1446

\begin{abstract}
Hepatocellular carcinoma (HCC) is the fifth most common cancer worldwide and the third highest cause of cancer-related mortality in humans. Epigallocatechin-3-gallate (EGCG) has been shown to inhibit the metastatic activity of certain cancer cells. The aim of this study was to determine the effects and molecular mechanism(s) of action of EGCG in human HCC cells. A migration and invasion assay for the metastatic behavior of HCCLM6 cells was performed. The antimetastatic effects of EGCG were investigated by RT-PCR and gelatin zymography. A total cellular protein profile was obtained using 2-dimensional gel electrophoresis (2-DE), followed by matrix-assisted laser desorption/ionization-time of flight mass spectrometry (MALDI-TOF-MS) analyses of proteins with significant differences in expression following treatment with EGCG. The results revealed that EGCG induced apoptosis and inhibited the metastasis of HCCLM6 cells. The anti-metastatic effects of EGCG were associated with the inhibition of matrix metalloproteinase (MMP)-2 and MMP-9 activity. The expression levels of far upstream element (FUSE) binding protein 1 (FUBP1), heat shock protein beta 1 (HSPB1), heat shock $60 \mathrm{kDa}$ protein 1 (chaperonin) (CH60) and nucleophosmin (NPM) proteins, which are associated with metastasis, were significantly altered in the EGCG-treated HCCLM6 cells. The data from the present study suggest that EGCG has potential as a therapeutic agent for the treatment of HCC.
\end{abstract}

Correspondence to: Professor Yi Xin, Department of Biotechnology, Dalian Medical University, 9 Western Section, Lushun Road South, Dalian, Liaoning 116044, P.R. China

E-mail: jimxinzyj@sina.cn

Abbreviations: HCC, hepatocellular carcinoma; EGCG, epigallocatechin-3-gallate; 2-DE, 2-dimensional gel electrophoresis; MTT, 3-(4,5-dimethylthiazol-2-yl)-2,5-diphenyltetrazolium bromide

Key words: epigallocatechin-3-gallate, hepatocellular carcinoma, metastasis, 2-dimensional gel electrophoresis

\section{Introduction}

Hepatocellular carcinoma (HCC) is the fifth most common cancer worldwide and the third highest cause of cancer-related mortality (500,000 deaths annually) (1). HCC is a primary malignant tumor of the liver with high prevalence in Asia and Africa (2). There are a number of different therapies for the treatment of $\mathrm{HCC}$, including percutaneous ethanol injection therapy (PEIT), transcatheter arterial chemoembolization (TACE), liver transplantation and surgical intervention. Of these, surgical intervention has been the most effective therapy for improving the survival of patients (3). Nevertheless, only a small subset of HCC patients increase their 5-year survival rate by surgical resection, primarily due to the high rate of metastasis and the expression of anti-apoptotic genes associated with HCC $(4,5)$. Therefore, metastasis remains the major obstacle to the development of optimal treatment methods for $\mathrm{HCC}$, and novel or adjunct therapeutic strategies are paramount to overcoming this obstacle.

Tea is the most widely consumed beverage worldwide; furthermore, green tea is sold on a large scale, in part, due to its chemotherapeutic value $(6,7)$. Catechins constitute approximately $40 \%$ of the dry weight of green tea, and epigallocatechin-3-gallate (EGCG), a polyphenol, constitutes the highest percentage among the catechins (8-10). EGCG has immense potential as a therapeutic agent for the treatment and/ or prevention of cancer due to its low cost and high bioavailability (11). The anticancer role of EGCG has been investigated epidemiologically, in in vitro and in vivo models, as well as in clinical trials (12-14). In vitro studies have demonstrated the inhibitory effects of EGCG on cancer by suppressing metastasis $(13,15,16)$. There is also a large body of evidence demonstrating the effects of EGCG on the migration ability of several human cancer cell lines by a multifactorial mechanism involving the downregulation of matrix metalloproteinases (MMPs) $(15,17)$. Yet, the precise mechanisms of action of EGCG as an anticancer agent remain unknown.

To our knowledge, the potential effects of EGCG on HCCLM6, a human HCC metastatic cell line, have not been previously reported. Thus, in this study, we investigated the effects and molecular mechanisms of action of EGCG in 
HCCLM6 cells as a novel and/or adjunct therapeutic agent in the treatment of HCC.

\section{Materials and methods}

Antibodies and reagents. EGCG ( $(29 \%$ purity), 3-(4,5-dimethylthiazol-2-yl)-2,5-diphenyltetrazolium bromide (MTT) and gelatin were purchased from Sigma (St. Louis, MO, USA). The RNA PCR kit (AMV) was purchased from the Takara Biotechnology Co., Ltd. (Dalian, China). DMEM and fetal bovine serum (FBS) were purchased from Gibco (Grand Island, NY, USA). TRIzol was purchased from Invitrogen (Camarillo, CA, USA). The Pierce ${ }^{\circledR}$ SilverStain for Mass Spectrometry kit was purchased from Thermo Scientific (Rockford, IL, USA). Immobilized $\mathrm{pH}$ gradient (IPG) strips and the 2-D Cleanup kit were purchased from Bio-Rad (Hercules, CA, USA). The BCA protein assay kit was purchased from KeyGen Biotech. Co. Ltd. (Nanjing, China), and 24-well, double-compartment Transwell plates were purchased from Corning Inc. (Lowell, MA, USA).

Cells and culture. HCCLM6 cells (ATCC, Manassas, VA, USA) were grown in DMEM supplemented with $10 \%$ heatinactivated FBS, $0.1 \%$ benzyl penicillin and streptomycin. Cells were maintained at $37^{\circ} \mathrm{C}$ in a humidified incubator with an atmosphere of $5 \% \mathrm{CO}_{2}$.

Cell viability assay. HCCLM6 cells $\left(6 \times 10^{3}\right.$ cells/well) were plated in 96-well plates for $12 \mathrm{~h}$. The cells were treated with various concentrations $(0,5,10,20,30,40,50,60,80$ or $100 \mu \mathrm{g} / \mathrm{ml}$ ) of EGCG and incubated for an additional $24 \mathrm{~h}$. At the end of the treatment, the culture medium was replaced with fresh complete medium containing $0.5 \mathrm{mg} / \mathrm{ml}$ MTT and incubated at $37^{\circ} \mathrm{C}$ for $4 \mathrm{~h}$. Following incubation, the medium was discarded, and DMSO was added to the wells and gently agitated for $10 \mathrm{~min}$. The absorbance was then measured at $490 \mathrm{~nm}$. The assay was repeated at least 3 times. The cell growth inhibition rates were calculated according to the following formula: inhibition rate $(\%)=(1-$ mean absorbance of treated group/mean absorbance of untreated group) $\mathrm{x} 100 \%$.

In vitro migration and invasion assays. The 24 -well Transwell plates and $8.0 \mu \mathrm{m}$ pore filter inserts (Corning Inc.) were used for the migration and invasion assays according to the standard Boyden Chamber protocol. Briefly, HCCLM6 cells were seeded in a 6-well plate, and at $80 \%$ confluency, the cells were treated with 0,5 or $10 \mu \mathrm{g} / \mathrm{ml}$ EGCG and incubated for $18 \mathrm{~h}$. The cells were harvested, counted and diluted to $5 \times 10^{5} / \mathrm{ml}$ of viable cells in medium without FBS. The cell suspension $(0.2 \mathrm{ml})$ was placed on top of the filter of the upper chamber, and $0.6 \mathrm{ml}$ of complete medium was placed in the lower chamber. The filter insert was placed into the lower chamber and incubated for $18 \mathrm{~h}$ at $37^{\circ} \mathrm{C}$. Non-migrated cells were removed from the top side of the filter by scrubbing with a cotton-tipped swab moistened with FBS-free medium. Migrated cells on the underside of the filter were fixed in $20 \%$ methanol for $20 \mathrm{~min}$, stained with $0.1 \%$ crystal violet at $37^{\circ} \mathrm{C}$ for $30 \mathrm{~min}$ and then washed with PBS. The invasion assay was carried out as described above, except that the top side of the filter membrane was pre-coated with $50 \mu \mathrm{l}$ of Matrigel $(0.3 \mathrm{mg} / 50 \mu \mathrm{l}$; Bio-Rad) and incubated for $5 \mathrm{~h}$ at $37^{\circ} \mathrm{C}$ to allow the matrix to form a gel before seeding the cells onto it. Stained cells were photographed at x200 magnification using a Nikon camera fitted to a Leica microscope (Leica Microsystems, Wetzlar, Germany).

Gelatin zymography. The HCCLM6 cells $\left(1 \times 10^{5}\right)$ were seeded in a 6-well plate. At $80 \%$ confluency, the cells were treated with $0,5,10$ or $20 \mu \mathrm{g} / \mathrm{ml}$ EGCG and incubated for $18 \mathrm{~h}$. Following incubation, the cells and medium were harvested and centrifuged $(1,000 \mathrm{rpm}$ for $5 \mathrm{~min})$ to collect the supernatant. The supernatants from the samples were normalized to the cell number and electrophoresed on a $10 \%$ polyacrylamide gel containing $1 \mathrm{mg} / \mathrm{ml}$ gelatin at $4^{\circ} \mathrm{C}$. Following electrophoresis, the gels were washed for $15 \mathrm{~min}$ in $2.5 \%$ Triton X-100 4 times at room temperature and then incubated for $24 \mathrm{~h}$ at $37^{\circ} \mathrm{C}$ in activation buffer $\left(50 \mathrm{mM}\right.$ Tris- $\mathrm{HCl}, \mathrm{pH} 7.5 ; 5 \mathrm{mM} \mathrm{CaCl}_{2}$; $10 \mathrm{mM} \mathrm{NaCl} ; 10 \mathrm{mM} \mathrm{ZnCl} 2$ ). The gels were stained with $0.2 \%$ coomassie brilliant blue (Ameresco Co., Framingham, MA, USA) for $3 \mathrm{~h}$ and then destained in destaining buffer (30\% methanol, $10 \%$ acetic acid) until the gelatinolytic activity of the MMPs are visible.

$R T$-PCR. The HCCLM6 cells $\left(3 \times 10^{5}\right)$ were seeded in 6-well plates until they reached $80 \%$ confluency. The cells were treated with $0,5,10$ and $20 \mu \mathrm{g} / \mathrm{ml}$ EGCG or 0,10 and $30 \mu \mathrm{g} / \mathrm{ml} \mathrm{EGCG}$ and incubated for $20 \mathrm{~h}$. Total RNA was extracted with TRIzol according to the manufacturer's instructions (Invitrogen). Semi-quantification and purity assessment were performed by optical density (OD) measurements at 260 and $280 \mathrm{~nm}$. cDNA was synthesized from the total RNA using an RNA PCR kit (Takara Biotechnology Co., Ltd.). The primers were derived from human sequences (Table I), and the PCR conditions were optimized until the gene products were within the linear phase of PCR amplification. The PCR products were resolved on $1 \%$ $(w / v)$ agarose gels containing ethidium bromide. The results were normalized to $\beta$-actin. The PCR conditions for each target gene (MMP-2, MMP-9 and $\beta$-actin) were as follows: $95^{\circ} \mathrm{C}$ for $5 \mathrm{~min} ; 30$ cycles of $95^{\circ} \mathrm{C}$ for $30 \mathrm{sec}, 55^{\circ} \mathrm{C}$ for $30 \mathrm{sec}$ and $72^{\circ} \mathrm{C}$ for $30 \mathrm{sec} ; 72^{\circ} \mathrm{C}$ for $10 \mathrm{~min}$.

Proteomic analysis of EGCG-treated cells. The HCCLM6 cells were plated as described above and treated with EGCG $(0$ or $20 \mu \mathrm{g} / \mathrm{ml}$ ). Total protein was extracted and pre-treated with the 2-D Cleanup kit (Bio-Rad). Isoelectrofocusing (IEF) was performed using $7 \mathrm{~cm}$ IPG strips (Bio-Rad) with an immobilized $\mathrm{pH}$ gradient from 3-10. The strips were rehydrated at room temperature for $16 \mathrm{~h}$ with $125 \mu \mathrm{l}$ of swelling buffer (8 mol/1 urea, 2\% CHAPS, 2\% IPG buffer, $0.3 \%$ DTT and a trace of bromophenol blue), which contained $45 \mu \mathrm{g}$ of pretreated proteins from either the EGCG-treated or untreated cells. IEF was performed at $200 \mathrm{~V}$ for $20 \mathrm{~min}, 450 \mathrm{~V}$ for $15 \mathrm{~min}, 750 \mathrm{~V}$ for $15 \mathrm{~min}$ and $3,000 \mathrm{~V}$ for $2 \mathrm{~h}$. Following IEF, the strips were immediately equilibrated with the equilibrium sample buffer $(50 \mathrm{mmol} / \mathrm{l}$ Tris-HCl, $\mathrm{pH} 8.8 ; 6 \mathrm{~mol} / \mathrm{l}$ urea; $30 \%$ glycerol; $2 \%$ SDS; and a trace of bromophenol blue) at room temperature for $30 \mathrm{~min}$ with gentle shaking. SDS-PAGE was performed using 12\% SDS-polyacrylamide gels. The strips were held in place with $0.5 \%$ agarose dissolved in SDS running buffer, and electrophoresis was then performed $(5 \mathrm{~mA}$ for $20 \mathrm{~min}, 15 \mathrm{~mA}$ for $20 \mathrm{~min}, 20 \mathrm{~mA}$ for $20 \mathrm{~min}$, and $30 \mathrm{~mA}$ 
Table I. Primer sequences and PCR conditions.

\begin{tabular}{llccc}
\hline Gene & \multicolumn{1}{c}{ Primer sequences } & PCR cycles (30 cycles) & Amplicon (bp) \\
\hline MMP-2 & Sense: & 5'-ATGACAGCTGCACCACTGAG-3' & $95^{\circ} \mathrm{C}, 30 \mathrm{sec}$ & 673 \\
& Antisense: 5'-GCCTCGTATACCGCATCAAT-3' & $55^{\circ} \mathrm{C}, 30 \mathrm{sec}$ & \\
& & & $72^{\circ} \mathrm{C}, 30 \mathrm{sec}$ & \\
MMP-9 & Sense: & 5'-GTGCTGGGCTGCTGCTTTGCTG-3' & $95^{\circ} \mathrm{C}, 30 \mathrm{sec}$ & 303 \\
& Antisense: 5'-GTCGCCCTCAAAGGTTTGGAAT-3' & $55^{\circ} \mathrm{C}, 30 \mathrm{sec}$ & \\
& & & $72^{\circ} \mathrm{C}, 30 \mathrm{sec}$ & 322 \\
$\beta$-actin & Sense: & 5'-GGAGTCCTGTGGCATCCACG-3' & $95^{\circ} \mathrm{C}, 30 \mathrm{sec}$ & \\
& Antisense: 5'-CTAGAAGCATTTGCGGTGGA-3' & $55^{\circ} \mathrm{C}, 30 \mathrm{sec}$ & $72^{\circ} \mathrm{C}, 30 \mathrm{sec}$ \\
\hline
\end{tabular}

MMP, matrix metalloproteinase.

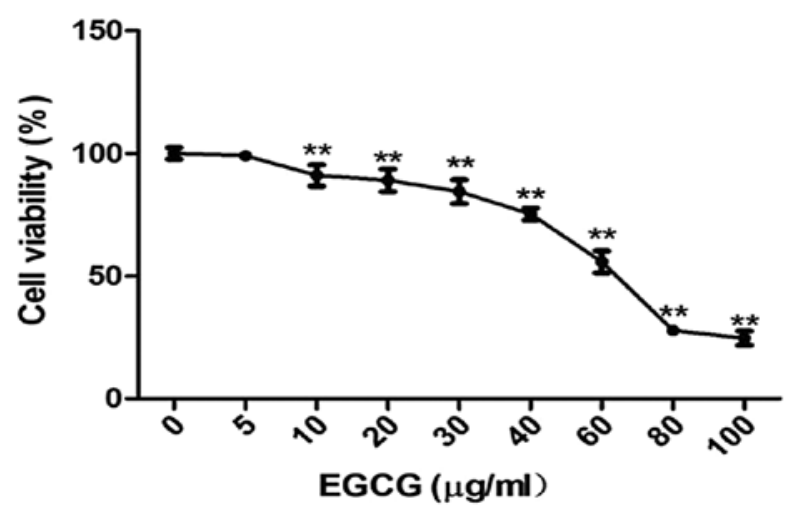

Figure 1. Growth inhibition of HCCLM6 cells by epigallocatechin-3-gallate (EGCG). The data are presented as the means \pm SD of 5 independent experiments. ${ }^{* *} \mathrm{P}<0.01$ compared with the control.

in $4^{\circ} \mathrm{C}$ for $2 \mathrm{~h}$ ). The gels were stained with the Silver Stain for Mass Spectrometry kit (Thermo Scientific) according to the manufacturer's instructions. Image analysis was performed using the PDQuest system (Bio-Rad). The selected spots were excised, and the proteins were purified by an in-gel digestion with trypsin. The resulting peptides were subjected to analysis by matrix-assisted laser desorption/ionization-time of flight mass spectrometry (MALDI-TOF/MS).

Statistical analysis. The results of all the experiments are expressed as the means \pm SD. Statistical analyses were performed using SPSS 13.0 software. A P-value $<0.05$ was considered to indicate a statistically significant difference.

\section{Results}

Effects of EGCG on cell viability. To determine the effect of EGCG on HCC, HCCLM6 cells were treated with EGCG at concentrations varying between 5 and $100 \mu \mathrm{g} / \mathrm{ml}$. EGCG $(10-100 \mu \mathrm{g} / \mathrm{ml})$ significantly inhibited the growth of HCCLM6 cells in a dose-dependent manner (Fig. 1) $(\mathrm{P}<0.01)$. These results indicate that EGCG inhibits cell growth (or induces apoptosis) in the HCC cell line, HCCLM6.
Effects of EGCG on cell migration and invasion. As indicated in Materials and methods, the 24-well Transwell membrane inserts had pores large enough to accommodate the migration (and/or the invasion) of single cells. The cells invading the underside of the 24-well Transwell membrane in these assays were fixed and stained (Fig. 2A and C). The cell migration analysis of HCCLM6 cells showed significantly lower $(\mathrm{P}<0.01)$ migration in the 5 and $10 \mu \mathrm{g} / \mathrm{ml}$ EGCG-treated cells compared with the untreated cells (Fig. 2B). The cell invasion analysis of HCCLM6 cells showed significantly lower $(\mathrm{P}<0.01)$ invasion in the 5 and $10 \mu \mathrm{g} / \mathrm{ml}$ EGCG-treated cells compared with the untreated cells (Fig. 2D).

Effect of EGCG on MMP-2 and MMP-9 activity. Gelatin zymography analysis indicated that treatment with EGCG significantly inhibited the activity of MMP- 2 and MMP-9 in the conditioned medium of HCCLM6 cells (Fig. 3A). The activity of MMP-2 and MMP-9 decreased in a dose-dependent manner with the increasing EGCG concentration (Fig. 3B and C, respectively).

Effect of EGCG on MMP-2 and MMP-9 gene expression. To determine the effects of EGCG on the mRNA levels of MMP-2 and MMP-9 genes, the HCCLM6 cells $\left(1 \times 10^{6}\right.$ cells $\left./ \mathrm{ml}\right)$ were maintained in culture with or without EGCG for $24 \mathrm{~h}$. Total RNA was isolated for RT-PCR as described above. As shown in Fig. 3D, the mRNA levels of MMP-2 and MMP-9 were downregulated in a dose-dependent manner by EGCG (Fig. 3E and F, respectively).

Proteomic analysis of EGCG-treated cells. The proteins from the EGCG-treated or untreated HCCLM6 cells were separated by 2-dimensional gel electrophoresis (2-DE) according to their isoelectric points and molecular weights. The 2-DE gels represent the pattern of all the proteins in the untreated and EGCG-treated HCCLM6 cells (Fig. 4A). Of the proteins whose expression was significantly altered by EGCG treatment, 10 were selected (data not shown) and analyzed by MALDI-TOF/MS. Using bioinformatics mining with the MASCOT search engine (http://www.matrixscience.com/) and NCBI BLASTP (http://www.ncbi.nlm.nih.gov/blast), we 


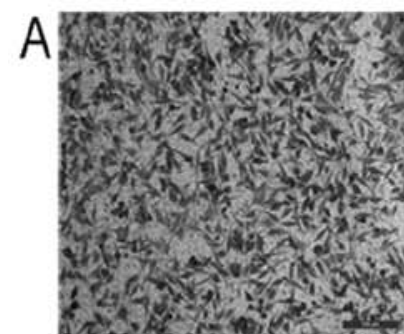

a

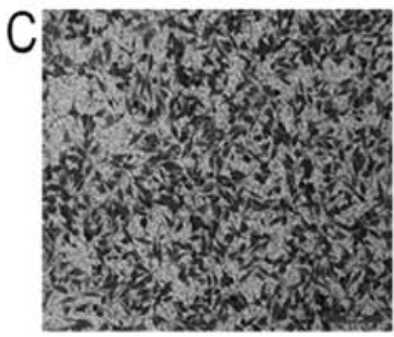

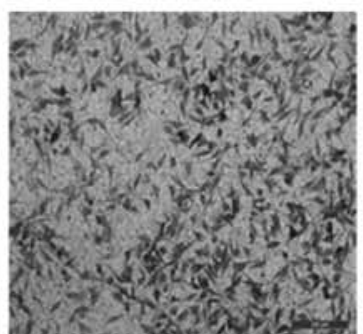

b

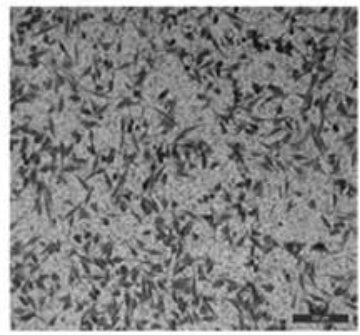

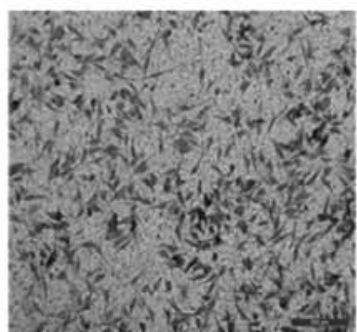

C

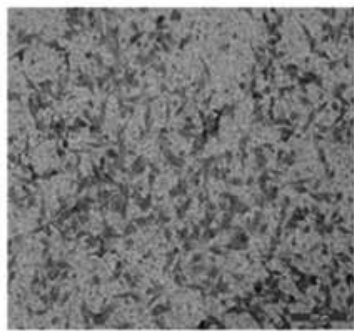

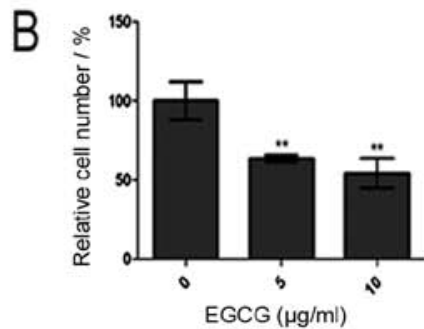

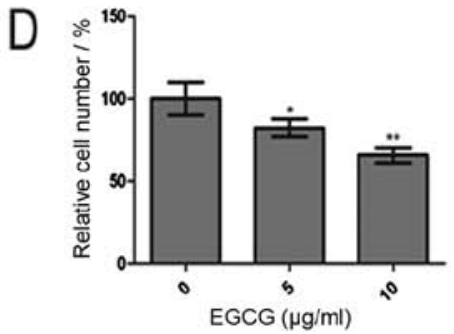

Figure 2. (A) Effect of epigallocatechin-3-gallate (EGCG) on cell migration. EGCG was used at the following doses: (a) $0 \mu \mathrm{g} / \mathrm{ml}$; (b) $5 \mu \mathrm{g} / \mathrm{ml}$; (c) $10 \mu \mathrm{g} / \mathrm{ml}$. Images, $\mathrm{x} 200$ magnification; scale bar, $200 \mu \mathrm{m}$. (B) The data are presented as the means \pm SD of 3 independent experiments. ${ }^{* *} \mathrm{P}<0.01$ compared with the control. (C) Effect of EGCG on cell invasion. EGCG was used at the following doses: (a) $0 \mu \mathrm{g} / \mathrm{ml}$; (b) $5 \mu \mathrm{g} / \mathrm{ml}$; (c) $10 \mu \mathrm{g} / \mathrm{ml}$. Images, x200 magnification; scale bar, $200 \mu \mathrm{m}$. (D) The data are presented as the means \pm SD of 3 independent experiments. ${ }^{* *} \mathrm{P}<0.01$ compared with the control.

A
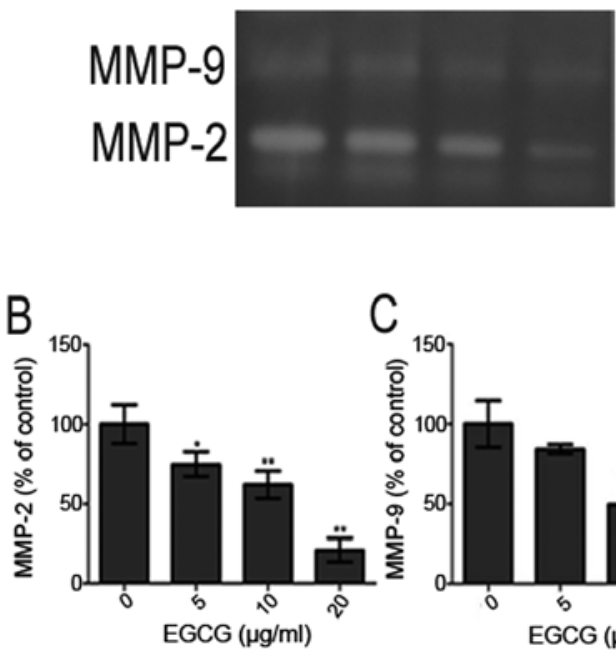

C

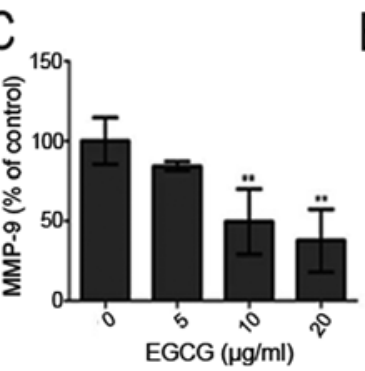

D

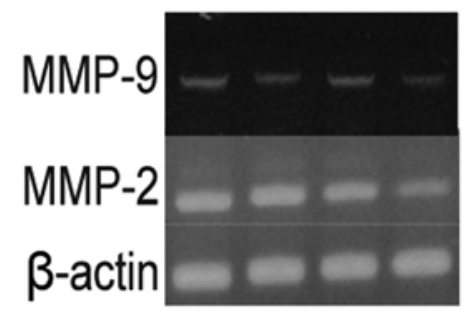

$\mathrm{F}$

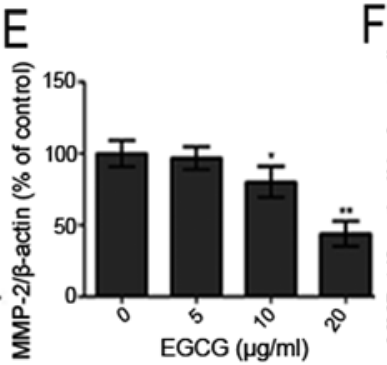

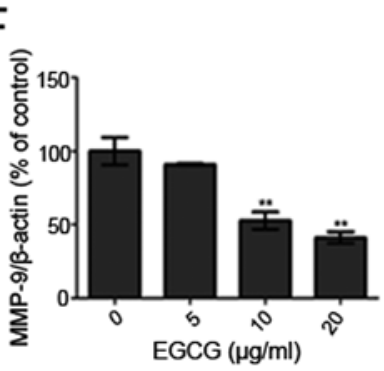

Figure 3. (A) Comparative zymography analysis of matrix metalloproteinase (MMP)-2 and MMP-9. (B) Graphic representation of MMP-2 and (C) MMP-9; the data are expressed as the means \pm SD of 3 independent experiments. ${ }^{*} \mathrm{P}<0.05,{ }^{* *} \mathrm{P}<0.01$, compared with the control. (D) RT-PCR analysis of MMP-2 and MMP-9. (E) MMP-2 and (F) MMP-9 mRNA expression normalized to $\beta$-actin; the data are expressed as the means $\pm \mathrm{SD}$ of 3 independent experiments. $\mathrm{P}<0.05$, ${ }^{* *} \mathrm{P}<0.01$, compared with the control.

determined significant functional differences (Table II) in 4 of these proteins (Fig. 4B).

\section{Discussion}

In this study, EGCG exhibited anticancer effects by clearly inhibiting the metastatic potential (migration and invasion) of HCCLM6 cells. MMP-2 and MMP-9 expression and enzyme activity correlated with the EGCG inhibition of metastasis, suggesting that EGCG prevents metastasis by inhibiting these enzymes (18). EGCG has been shown to inhibit tumor invasion and migration associated with MMPs in human breast cancer and pancreatic cancer cells $(15,19)$. Metastasis, the spread of cancer in the body, is a major cause of mortality (19). Collagenase type IV (containing MMP-2 and MMP-9) is a key enzyme involved in tumor invasion and migration, as demonstrated by the anti-metastatic effects of several collagenase inhibitors; some inhibitors have already been used in clinical trials (20). In our study, EGCG significantly inhibited HCCLM6 cell metastasis in a dose-dependent manner at both the mRNA expression and protein (enzyme) activity levels (Figs. 3 and 4). These results suggest that EGCG inhibits the metastasis of HCCLM6 cells through the downregulation of MMPs.

To further understand the effects of EGCG on HCCLM6 cells and to identify potential novel therapeutic targets for $\mathrm{HCC}$, the protein profiles of EGCG-treated and untreated cells were 
Table II. Characteristics of the 4 proteins with significant functional differences and their relative expression levels in HCCLM6 cells treated with EGCG.

\begin{tabular}{|c|c|c|c|c|c|c|}
\hline $\begin{array}{l}\text { Spot } \\
\text { no. }\end{array}$ & Protein(s) identified & $\begin{array}{c}\text { Accession } \\
\text { no. }\end{array}$ & $\begin{array}{l}\text { Molecular } \\
\text { mass }\end{array}$ & $\mathrm{pI}$ & Score & $\begin{array}{c}\text { Spot } \\
\text { intensity }\end{array}$ \\
\hline 1 & Far upstream element binding protein 1 (FUBP1) & Q96AE4 & 67690 & 7.18 & 96 & $\mathrm{C}^{\mathrm{a}}$ \\
\hline 2 & Heat shock protein beta 1 (HSPB1) & P04792 & 22826 & 5.98 & 70 & $\mathrm{a}^{\mathrm{a}}$ \\
\hline 3 & Nucleophosmin (NPM) & P06748 & 32726 & 4.64 & 83 & $t^{\mathrm{a}}$ \\
\hline 4 & Heat shock $60 \mathrm{kDa}$ protein 1 (chaperonin) $(\mathrm{CH} 60)$ & P10809 & 61187 & 5.70 & 82 & $-^{\mathrm{a}}$ \\
\hline
\end{tabular}

Results are based on the NCBInr database using the MASCOT search program with our mass spectrometry (MS)/MS data; +, increased spot intensity in HCCLM6 cells treated with EGCG; -, decreased spot intensity in HCCLM6 cells treated with EGCG. ${ }^{\mathrm{a} P<0.01 . ~ E G C G, ~}$ epigallocatechin-3-gallate; pI, isoelectric point.

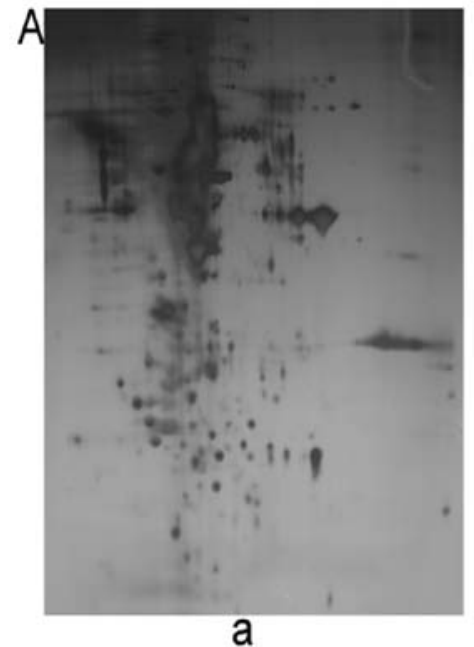

a

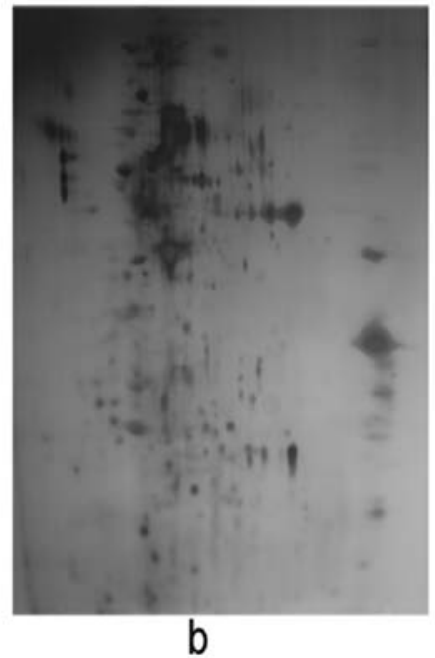

b

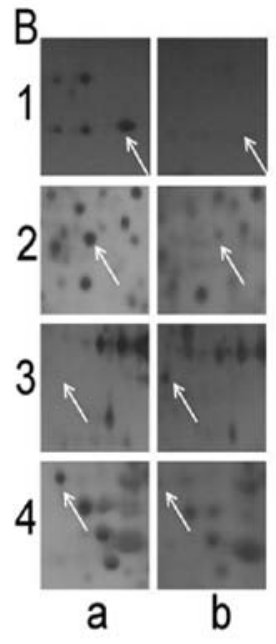

Figure 4. (A) 2-dimensional gel electrophoresis of total proteins from HCCLM6 cells treated (a) without epigallocatechin-3-gallate (EGCG) or (b) with $30 \mu \mathrm{g} /$ $\mathrm{ml}$ EGCG. The isoelectric point (pI) ranges from 3.5 to 9.5 (left to right panel), and the molecular mass ranges from 130 to $10 \mathrm{kDa}$ (top to bottom). (B) Enlarged panels (1-4) of 4 proteins with significant functional differences in (a) untreated and (b) $30 \mu \mathrm{g} / \mathrm{ml}$ EGCG-treated HCCLM6 cells.

analyzed. We identified 4 proteins associated with cell growth and proliferation: far upstream element binding protein 1 (FUBP1), heat shock protein (HSP)B1, heat shock $60 \mathrm{kDa}$ protein 1 (chaperonin) (CH60) and nucleophosmin (NPM) (Table II). FUBP1 is a DNA binding protein that activates the far upstream element of c-Myc to stimulate its expression in HCC $(21,22)$. FUBP1 functions as an ATP-dependent DNA helicase, which is overexpressed in soft tissue metastasis, and has been shown to be an important element in the progression of breast cancer metastasis (23). Therefore, FUBP1 may be an important component in the overall metastatic process of HCC. Panel 1 of Fig. 4B shows the decreased expression of FUBP1 protein following treatment with EGCG. EGCG antimetastatic activity in HCCLM6 and in HCC, in general, may involve FUBP1 through a molecular mechanism similar to that proposed in other soft tissues (23).

HSPB1, also known as HSP27, belongs to the ubiquitous family of small HSPs. In panel 2 of Fig. 4B, the enlarged 2-DE gel image shows a significant reduction in HSPB1 expression following treatment with EGCG. In MDA-MB-231 breast cancer cells, increased HSPB1 expression has been shown to enhance metastasis through the upregulation of MMP-9 $(24,25)$. HSP27 is a potent therapeutic target in breast cancer bone metastasis; the anti-metastatic agent, midazolium trans-imidazole dimethyl sulfoxide tetrachlororuthenate (NAMI-A), has been shown to decrease HSP27 protein expression (26). In the present study, we hypothesized that treatment with EGCG may have decreased HSP27 expression by downregulating MMP-9 and reducing HCCLM6 cancer cell metastasis (Table II and Fig. 3).

NPM is a multifunctional protein that shuttles between the nucleoli and the cytoplasm, functioning as a chaperone for the nuclear export of ribosomal subunits $(27,28)$. NPM shifts its location from the nucleolus to the nucleoplasm (NPM translocation) and accumulates if cells are exposed to actinomycin $\mathrm{D}$, doxorubicin, or other DNA damaging agents $(29,30)$. In our study, treatment with EGCG significantly increased NPM expression in HCCLM6 cells (Fig. 4B, panel 3). HeLa cells exposed to longterm and/or to high doses of actinomycin D (or other antibiotics with anticancer activity) have shown a significant accumulation of NPM in the nucleoplasm, which antagonizes both cell growth and RNA synthesis (29). EGCG may impair RNA synthesis, RNA processing and cell growth due to a loss of NPM binding targets in the nucleolus, which may cause it to accumulate in the nucleoplasm. The resulting loss of ribosomal assembly integrity may inhibit cellular growth (and/or metastasis) in HCCLM6 cells. In a recent study, increased NPM expression levels were 
suggested to enhance cellular transformation, antagonize the repression of cell adhesion genes and inhibit apoptosis mediated by the Myc-Mizl complex if the alternate reading frame (Arf) tumor suppressor protein is present (31). These contradicting observations of NPM expression in cancer require further investigation to clearly define the 'antagonistic' function of this protein, either enhancing or reducing carcinogenesis and/or tumor progression.

$\mathrm{CH} 60$ has been associated with tumor metastasis by regulating tumor immunity $(32,33)$. The overexpression of HSP60 has been shown to increase the migration and invasive potential of human pharyngeal squamous carcinoma cells (FADU cells) in vitro and in vivo (34). The enlargement of the 2-DE gel in panel 4 of Fig. 4B shows a significant loss of CH60 expression in the HCCLM6 cells following treatment with EGCG. CH60 may be a critical factor in the anti-metastatic activity of EGCG in HCCLM6 cells.

The present study demonstrates that EGCG inhibits HCCLM6 cell metastasis by inhibiting MMP-2, MMP-9, FUBP1, HSPB1 and CH60 expression and increasing NPM expression. However, further studies are required to investigate the specific anti-metastatic mechanisms of action of EGCG and its effects on FUBP1, HSPB1, NPM and CH60 expression in cells in vitro and in vivo. Nevertheless, the data from the present study suggest that EGCG has potential as an anticancer agent in the treatment of HCC.

\section{References}

1. Parkin DM, Bray F, Ferlay J and Pisani P: Estimating the world cancer burden: Globocan 2000. Int J Cancer 94: 153-156, 2001.

2. El-Serag HB and Mason AC: Rising incidence of hepatocellular carcinoma in the United States. N Engl J Med 340: 745-750, 1999.

3. Ikai I, Yamaoka Y, Yamamoto Y, et al: Surgical intervention for patients with stage IV-A hepatocellular carcinoma without lymph node metastasis: proposal as a standard therapy. Ann Surg 227: 433-439, 1998

4. Lee JS, Chu IS, Heo J, Calvisi DF, et al: Classification and prediction of survival in hepatocellular carcinoma by gene expression profiling. Hepatology 40: 667-676, 2004.

5. Song HY, Liu YK, Feng JT, et al: Proteomic analysis on metastasis-associated proteins of human hepatocellular carcinoma tissues. J Cancer Res Clin Oncol 132: 92-98, 2006.

6. Shukla Y: Tea and cancer chemoprevention: a comprehensive review. Asian Pacific J Cancer Prev 8: 155-165, 2007.

7. Yang CS, Wang X, Lu G and Picinich SC: Cancer prevention by tea: animal studies, molecular mechanisms and human relevance. Nat Rev Cancer 9: 429-439, 2009.

8. Yang CS and Wang ZY: Tea and cancer. J Natl Cancer Inst 85: 1038-1049, 1993

9. Balentine DA, Wiseman SA and Bouwens LCM: The chemistry of tea flavonoids. Crit Rev Food Sci Nutr 37: 693-704, 1997.

10. Mukhtar H and Ahmad N: Green tea in chemoprevention of cancer. Toxicol Sci 52: 111-117, 1999.

11. Singh BN, Shankar S and Srivastava RK: Green tea catechin, epigallocatechin-3-gallate (EGCG): mechanisms, perspectives and clinical applications. Biochem Pharmacol 82: 1807-1821, 2011.

12. Thawonsuwan J, Kiron V, Satoh S, et al: Epigallocatechin-3gallate (EGCG) affects the antioxidant and immune defense of the rainbow trout, Oncorhynchus mykiss. Fish Physiol Biochem 36: 687-697, 2010.

13. Mukhtar $\mathrm{H}$ and Ahmad N: Tea polyphenols: prevention of cancer and optimizing health. Am J Clin Nutr 71 (Suppl 6): S1698-S1702, 2000.

14. Thangapazham RL, Singh AK, Sharma A, et al: Green tea polyphenols and its constituent epigallocatechin gallate inhibits proliferation of human breast cancer cells in vitro and in vivo Cancer Lett 245: 232-241, 2007.
15. Shankar S, Ganapathy S, Hingorani SR and Srivastava RK: EGCG inhibits growth, invasion, angiogenesis and metastasis of pancreatic cancer. Front Biosci 13: 440-452, 2008

16. Stuart EC, Scandlyn MJ and Rosengren RJ: Role of epigallocatechin gallate (EGCG) in the treatment of breast and prostate cancer. Life Sci 79: 2329-2336, 2006.

17. Sen T, Moulik S, Dutta A, et al: Multifunctional effect of epigallocatechin-3-gallate (EGCG) in downregulation of gelatinase-A (MMP-2) in human breast cancer cell line MCF-7. Life Sci 84: 194-204, 2009.

18. Lee SJ, Lee KW, Hur HJ, Chun JY, Kim SY and Lee HJ: Phenolic phytochemicals derived from red pine (Pinus densiflora) inhibit the invasion and migration of SK-Hep-1 human hepatocellular carcinoma cells. Ann NY Acad Sci 1095: 536-544, 2007.

19. Woodhouse EC, Chuaqui RF and Liotta LC: General mechanisms of metastasis. Cancer 80 (Suppl 8): S1529-S1537, 1997.

20. Hidalgo $\mathrm{M}$ and Eckhardt SG: Development of matrix metalloproteinase inhibitors in cancer therapy. J Natl Cancer Inst 93: 178-193, 2001.

21. Duncan R, Bazar L, Michelotti G, Tomonaga T, Krutzsch H, Avigan $M$ and Levens D: A sequence-specific, single-strand binding protein activates the far upstream element of c-myc and defines a new DNA-binding motif. Genes Dev 8: 465-480, 1994.

22. Zubaidah RM, Tan GS, Tan SB, Lim SG, Lin Q and Chung MC: 2-D DIGE profiling of hepatocellular carcinoma tissues identified isoforms of far upstream binding protein (FUBP) as novel candidates in liver carcinogenesis. Proteomics 8: 5086-5096, 2008.

23. Sanz R, Aragüés R, Stresing V, Martín B, Landemaine T, Oliva B, et al: Functional pathways shared by liver and lung metastases: a mitochondrial chaperone machine is up-regulated in soft-tissue breast cancer metastasis. Clin Exp Metastasis 24: 673-683, 2007.

24. Hansen RK, Parra I, Hilsenbeck SG, Himelstein B and Fuqua SA: Hsp27-induced MMP-9 expression in influenced by the Src tyrosine protein kinase yes. Biochem Biophys Res Commun 282: 186-193, 2001.

25. Gibert B, Eckel B, Gonin V, Goldschneider D, Fombonne J, Deux B, et al: Targeting heat shock protein 27 (HspB1) interferes with bone metastasis and tumour formation in vivo. Br J Cancer 107: 63-70, 2012.

26. Sanna B, Debidda M, Pintus G, et al: The anti-metastatic agent imidazolium trans-imidazoledimethylsulfoxide-tetrachlororuthenate induces endothelial cell apoptosis by inhibiting the mitogen-activated protein kinase/extracellular signal-regulated kinase signaling pathway. Arch Biochem Biophys 403: 209-218, 2002.

27. Borer RA, Lehner CF, Eppenberger HM and Nigg EA: Major nucleolar proteins shuttle between nucleus and cytoplasm. Cell 56: 379-390, 1989.

28. Maggi LB Jr, Kuchenruether M, Dadey DY, Schwope RM, Grisendi S, Townsend RR, et al: Nucleophosmin serves as a ratelimiting nuclear export chaperone for the Mammalian ribosome. Mol Cell Biol 28: 7050-7065, 2008.

29. Yung BY, Bor AM and Chan PK: Short exposure to actinomycin D induces 'reversible' translocation of protein B23 as well as 'reversible' inhibition of cell growth and RNA synthesis in HeLa cells. Cancer Res 50: 5987-5991, 1990.

30. Chan PK and Chan FY: A study of correlation between NPM-translocation and apoptosis in cells induced by daunomycin. Biochem Pharmacol 57: 1265-1273, 1999.

31. Herkert B, Dwertmann A, Herold S, Abed M, Naud JF, Finkernagel F, et al: The Arf tumor suppressor protein inhibits Miz1 to suppress cell adhesion and induce apoptosis. J Cell Biol 188: 905-918, 2010.

32. Feng Y, Tian ZM, Wan MX and Zheng ZB: Protein profile of human hepatocarcinoma cell line SMMC-7721: identification and functional analysis. World J Gastroenterol 13: 2608-2614, 2007.

33. Jiang D, Ying W, Lu Y, Wan J, Zhai Y, Liu W, et al: Identification of metastasis-associated proteins by proteomic analysis and functional exploration of interleukin-18 in metastasis. Proteomics 3: 724-737, 2003

34. Tsai YP, Yang MH, Huang CH, et al: Interaction between HSP60 and beta-catenin promotes metastasis. Carcinogenesis 30: 1049-1057, 2009. 